\title{
The montane trees of the Cameroon Highlands, West-Central Africa, with Deinbollia onanae sp. nov. (Sapindaceae), a new primate-dispersed, Endangered species
}

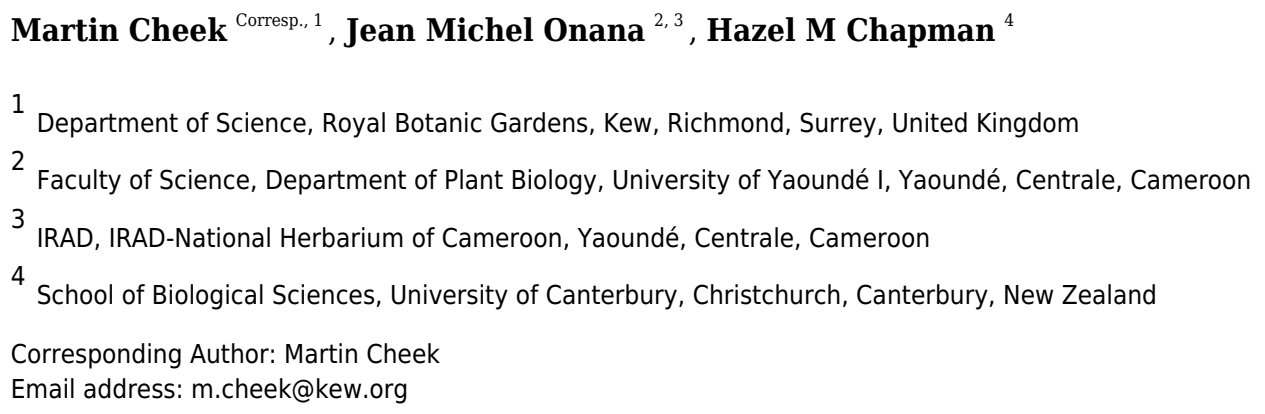

We test the hypothesis that the tree species previously known as Deinbollia sp. 2. is a new species for science. We formally characterise and name this species as Deinbollia onanae (Sapindaceae-Litchi clade) and we discuss it in the context of the assemblage of montane tree species in the Cameroon Highlands of West-Central Africa. The new species is a shade-bearing, non-pioneer understorey forest tree species reaching $15 \mathrm{~m}$ high and a trunk diameter that can attain over $40 \mathrm{~cm}$ at $1.3 \mathrm{~m}$ above the ground. Seed dispersal has been recorded by chimpanzees (Pan troglodytes ellioti) and by putty-nose monkeys (Cercopithecus nictitans) and the species is used by chimpanzees for nesting. Cameroon has the highest species-diversity and species endemism known in this African-Western Indian Ocean genus of 42 , mainly lowland species. Deinbollia onanae is an infrequent tree species known from six locations in surviving islands of montane (sometimes also upper submontane) forest along the line of the Cameroon Highlands, including one at Ngel Nyaki in Mambilla, Nigeria. Deinbollia onanae is here assessed as Endangered according to the IUCN 2012 standard, threatened by severe fragmentation of its mountain forest habitat due to extensive and ongoing clearance for agriculture. The majority of the 28 tree species of montane forest (above $2000 \mathrm{~m}$ alt.) in the Cameroon Highlands are also widespread in East African mountains (i.e. are Afromontane wide). Deinbollia onanae is one of only seven species known to be endemic (globally restricted to) these highlands. It is postulated that this new species is morphologically closest to Deinbollia oreophila, a frequent species at a lower (submontane) altitudinal band of the same range. Detailed ecological data on Deinbollia onanae from the Nigerian location, Ngel Nyaki, where it has been known under the name Deinbollia "pinnata", is reviewed. 
1 The montane trees of the Cameroon Highlands, West-Central Africa, with

2 Deinbollia onanae sp. nov. (Sapindaceae), a new primate-dispersed, Endangered

3 species

4

7 'Science, Royal Botanic Gardens, Kew, Richmond, Surrey, U.K.

$8 \quad{ }^{2}$ University of Yaoundé I, Faculty of Science, Department of Plant Biology P.O Box 812

9 Yaoundé, Cameroon

10 IRAD-National Herbarium of Cameroon Yaoundé, PO Box 1601, Cameroon

$11{ }^{4}$ School of Biological Sciences, University of Canterbury, PB 4800, Christchurch, New Zealand 12

13 Corresponding author:

14 Martin Cheek ${ }^{1}$

15

Email address: m.cheek@kew.org 


\section{ABSTRACT}

We test the hypothesis that the tree species previously known as Deinbollia $s p$. 2. is a new species for science. We formally characterise and name this species as Deinbollia onanae (Sapindaceae-Litchi clade) and we discuss it in the context of the assemblage of montane tree species in the Cameroon Highlands of West-Central Africa. The new species is a shade-bearing, non-pioneer understorey forest tree species reaching $15 \mathrm{~m}$ high and a trunk diameter that can attain over $40 \mathrm{~cm}$ at $1.3 \mathrm{~m}$ above the ground. Seed dispersal has been recorded by chimpanzees (Pan troglodytes ellioti) and by putty-nose monkeys (Cercopithecus nictitans) and the species is used by chimpanzees for nesting. Cameroon has the highest species-diversity and species endemism known in this African-Western Indian Ocean genus of 42, mainly lowland species. Deinbollia onanae is an infrequent tree species known from six locations in surviving islands of montane (sometimes also upper submontane) forest along the line of the Cameroon Highlands, including one at Ngel Nyaki in Mambilla, Nigeria. Deinbollia onanae is here assessed as Endangered according to the IUCN 2012 standard, threatened by severe fragmentation of its mountain forest habitat due to extensive and ongoing clearance for agriculture. The majority of the 28 tree species of montane forest (above $2000 \mathrm{~m}$ alt.) in the Cameroon Highlands are also widespread in East African mountains (i.e. are Afromontane wide). Deinbollia onanae is one of only seven species known to be endemic (globally restricted to) these highlands. It is postulated that this new species is morphologically close to Deinbollia oreophila, a frequent species at a lower (submontane) altitudinal band of the same range. Detailed ecological data on Deinbollia onanae from the Nigerian location, Ngel Nyaki, where it has been known under the name Deinbollia "pinnata", is reviewed. 
92

93

94

95

96

97

98

99

100

101

102

103

104

105

106

107

108

109

110

111

112

113

114

115

116

117

118

119

120

121

122

123

124

125

126

127

128

129

130

131

132

133

134

135

136

137

\section{INTRODUCTION.}

As part of the project to designate Important Plant Areas (IPAs) in Cameroon (also known as Tropical Important Plant Areas or TIPAs, https://www.kew.org/science/ourscience/projects/tropical-important-plant-areas-cameroon), we are striving to name, assess the conservation status and include in IPAs (Darbyshire et al., 2017) rare and threatened plant species in the threatened natural habitat of the Cross-Sanaga interval (Cheek et al., 2001).

Several of these species were previously designated as new to science but not formally published in a series of checklists (see below) ranging over much of the Cross-Sanaga interval. The CrossSanaga has the highest vascular plant species diversity per degree square in tropical Africa (Barthlott et al., 1996) but natural habitat is being steadily cleared, predominantly for agriculture.

In this paper we test the hypothesis that the high-altitude tree species formerly designated as "Deinbollia sp. 2" (Harvey et al., 2004, Cheek et al., 2004, Cheek et al., 2010), "Deinbollia sp." (Chapman \& Chapman, 2001) or "Deinbollia pinnata" (Abiem et al., 2020), is a new species to science, and we describe, characterise, and name it as Deinbollia onanae Cheek. The species is discussed in the context of the assemblage of the other montane forest tree species (occurring above $2000 \mathrm{~m}$ alt.) in the Cameroon Highlands (see Discussion below).

The genus Deinbollia Schum. \& Thonn. is traditionally placed in the tribe Sapindeae DC. and is characterised by its 1-pinnate, imparipinnate leaves, flowers with petals well developed and about the same in number as the imbricate sepals, the petals with a well-developed ligule (or appendage) on the adaxial surface and with stamens 9-30 in number, the intrastaminal disc central, the edge with more than 5 shallow ridges. The fruits develop 1-3 indehiscent, apocarpous fleshy mericarps (Fouilloy \& Hallé, 1973).

Molecular phylogenetic sampling of the Sapindaceae is incomplete with many African genera not represented, as can be seen in Buerki et al., (2009). In that study Deinbollia is represented by six samples of four species, all from Madagascar (on which limited basis it appears monophyletic) and is resolved in the informally named 'Litchi Group' of genera, where it is in a 
138 sister relationship to a subclade comprising the genera Lepisanthes Blume (Africa to Asia)

139 Atalaya Blume (American) and Pseudima Radlk. (American) (Buerki et al., 2009). The

140 delimitation of Sapindaceae in this paper follows the evidence of Buerki et al., (2010), that is,

141 excluding Aceraceae, Hippocastanaceae and Xanthoceraceae which have sometimes been

142 included within it.

143

144

145

Deinbollia has 42 accepted species, one shared between Africa, Reunion and Madagascar, five

146

147 endemic to Madagascar, and 35 species restricted to subsaharan continental Africa. The species predominantly occur in lowland evergreen forest and are absent from countries that lack this habitat such as Rwanda, Burundi, Swaziland, Lesotho (high altitude), Namibia, Botswana, Eritrea, Mali and Burkina Faso (low rainfall and lacking significant evergreen forest). The highest species diversity is found in Cameroon, with 16 species (Plants of the World Online accessed May 2020). Cameroon has the highest levels of country-level endemism known in the genus. Ten of the Cameroon species are globally threatened with extinction (Cheek in Onana \& Cheek 2011: 314-316; Cheek, 2004a; Cheek, 2017a; Cheek, 2017b). In contrast only 10 species are recorded for the whole of West Tropical Africa (Keay, 1958). Since the Flore du Cameroun account was published (Fouilloy \& Hallé, 1973), several further species apart from those listed below, were published for Cameroon by Thomas (1986). The genus was last revised by Radlkofer (1932).

In the $21^{\text {st }}$ century only two new species to science have been published in the genus, Deinbollia mezilii D.W.Thomas \& D.J.Harris (Thomas \& Harris, 2000) and D. oreophila Cheek (Cheek \& Etuge 2009), both from Cameroon. But specimens often remain unidentified in herbaria. For example, 16 specimens unidentified to species are listed in the Gabon Checklist (Sosef et al.,2005). The genus has no major uses, but the fruits of several species are reported as being edible by humans, and the seeds are probably primate-dispersed or dispersed by large frugivorous birds, and the flowers probably bee-pollinated (Cheek \& Etuge, 2009). Several species are recorded to be useful locally in West Africa especially medicinally, e.g., the bark of D. grandifolia Hook.f. is used for treating jaundice and the wood for planks (Burkill, 2000:1719).

\section{METHODS \& MATERIALS}

171

172

173

The electronic version of this article in Portable Document Format (PDF) will represent a published work according to the International Code of Nomenclature for algae, fungi, and plants (ICN), and hence the new names contained in the electronic version are effectively published under that Code from the electronic edition alone. In addition, new names contained in this work which have been issued with identifiers by IPNI will eventually be made available to the Global Names Index. The IPNI LSIDs can be resolved and the associated information viewed through any standard web browser by appending the LSID contained in this publication to the prefix "http://ipni.org/". The online version of this work is archived and available from the following digital repositories: PeerJ, PubMed Central, and CLOCKSS. 
182 Fieldwork in Cameroon resulting in the specimens cited in this paper was conducted under the

183 terms of the series of Memoranda of Collaboration between IRAD (Institute for Agronomic

184 Research and Development)-National Herbarium of Cameroon and Royal Botanic Gardens, Kew

185 beginning in 1992, the most recent of which is valid until $5^{\text {th }}$ Sept. 2021. The most recent

186 research permit issued for fieldwork under these agreements was

187 000146/MINRESI/B00/C00/C10/C12 (issued 28 Nov 2019), and the export permit number was

188 098/IRAD/DG/CRRA-NK/SSRB/12/2019 (issued 19 Dec 2019). At the Royal Botanic Gardens,

189 Kew, fieldwork was approved by the Institutional Review Board of Kew entitled the Overseas

190 Fieldwork Committee (OFC) for which the most recent registration number was OFC 807-3

191 (2019). The most complete set of duplicates for all specimens made was deposited at YA, the

192 remainder exported to K for identification and distribution following standard practice. Field

193 work methodology followed was Cheek \& Cable (1997).

194 Herbarium citations follow Index Herbariorum (Thiers et al., 2020). Specimens indicated "!"

195 were seen by one or more authors, and were studied at K, P, WAG, and YA. The National

196 Herbarium of Cameroon, YA, was also searched for additional material of the new taxon as was

197 Tropicos (http://legacy.tropicos.org/SpecimenSearch.aspx). During the time that this paper was

198 researched in 2019-2020, it was not possible to obtain physical access to material at WAG (due

199 to the transfer of WAG to Naturalis, Leiden, subsequent construction work, and covid-19 travel

200 and access restrictions). However images for WAG specimens were studied at

201 https://bioportal.naturalis.nl/?language=en and those from $\mathrm{P}$ at

202 https://science.mnhn.fr/institution/mnhn/collection/p/item/search/form?lang=en_US. Specimens

203 of Deinbollia at FHO could not be accessed due to covid-19 and are not available digitally.

204 Specimens at FHI are also not available digitally. We also searched JStor Global Plants (2020)

205 for additional type material of the genus not already represented at K.

206

207

208

209

210

211

212

213

214

215

216

217

218

219

Binomial authorities follow the International Plant Names Index (IPNI, 2020). The conservation assessment was made using the categories and criteria of IUCN (2012). GeoCAT was used to calculate red list metrics (Bachman et al., 2011). Herbarium material was examined with a Leica Wild M8 dissecting binocular microscope fitted with an eyepiece graticule measuring in units of $0.025 \mathrm{~mm}$ at maximum magnification. The drawing was made with the same equipment using Leica 308700 camera lucida attachment. Flowers from herbarium specimens of the new species described below were soaked in warm water to rehydrate the flowers, allowing dissection, characterisation, and measurement. The terms and format of the description follow the conventions of Cheek \& Etuge (2009). Georeferences for specimens lacking latitude and longitude were obtained using Google Earth (https://www.google.com/intl/en uk/earth/versions/ ). The map was made using SimpleMappr (https://www.simplemappr.net).

\section{RESULTS}

\section{TAXONOMIC TREATMENT}

221

222

223

224

225
Deinbollia sp. 2 (Fig. 1), because it has leaves of flowering branches less than $1 \mathrm{~m}$ long, only sparsely hairy on the lower surface, leaflets more than $15 \mathrm{~cm}$ long and sepals adaxially glabrous, flower buds very sparsely hairy and less than $5 \mathrm{~mm}$ diam., borne on a branched inflorescence 10-30 cm long, keys out in the Flore du Cameroun treatment of Deinbollia (Fouilloy \& Hallé, 
226

227

228

229

230

231

232

233

234

235

236

237

238

239

240

241

242

243

244

245

246

247

248

249

250

251

252

253

254

255

256

257

258

259

260

261

262

263
1973) to a couplet leading to D. grandifolia Hook.f. and D. maxima Gilg. However, it differs from these two species in having (2-)8-11-jugate leaves (not 4-7-jugate), and in other characters shown in Table 1. In its Nigerian location our species has been referred to as D. pinnata (Abiem et al., 2020). Deinbollia pinnata Schum. \& Thonn. is a common lowland West African species that occurs from Guinea to Nigeria, it differs in being densely hairy, so that the lower surface of the leaflets are softly hairy to the touch due to dense, patent, translucent hairs, and it is usually a small shrub of disturbed habitats, with an unbranched, raceme-like inflorescence that is pendulous in fruit, with hairy fruits $12-13 \mathrm{~mm}$ wide (see https://commons.wikimedia.org/wiki/File:Deinbollia pinnata_MS6765.jpg; Keay 1958: 714-715). In contrast, Deinbollia sp. 2 has only a very few, sparse, red, subappressed hairs along the midrib and secondary nerves, is a tree of intact high elevation forest, the inflorescence is erect, with numerous long branches bearing glabrous fruits $20 \mathrm{~mm}$ or more wide (see description below). Additional characters separating Deinbollia sp. 2 from Deinbollia pinnata are included in Table 1.

The affinities of Deinbollia sp. 2 may be with the recently described D. oreophila since this species also occurs at altitude in the Cameroon Highlands and both species share numerous raised lenticels and also leaflets with high length: breadth ratios and with high numbers of secondary nerves. Both species share an unusual structure which is also seen in Deinbollia pinnata: the adaxial surface of the leaf rhachis is not rounded as in the other West African species, but flattened, the margins slightly raised forming acute angles with the sides, with a distinct, raised midline (Cheek \& Onana, 2009: Fig. 1C). In fact, at two locations, Mt Kupe and Bali Ngemba, the two species D. oreophila and Deinbollia sp. 2 are sympatric and their altitudinal ranges can overlap (Cheek et al., 2004; Harvey et al., 2004). However, without DNA studies, convergent evolution cannot be ruled out. As the only two species of the genus to grow at altitude in the Cameroon Highlands, there is a possibility that they might be confused with each other. The two species can be separated using the morphological characters presented in Table 2.

Deinbollia onanae Cheek sp. nov. - Fig. 1-4

Similar to but differing from Deinbollia oreophila Cheek in the length of leaves of flowering stems (14-)60-70 cm (versus 25-63 cm), number of leaflets per leaf (4-)16-23 (versus (4-)6$8(-10)$ ), width of leaflets $(2.1-) 2.5-4 \mathrm{~cm}$ (versus $(3-) 5.5-9(-10.2) \mathrm{cm}$, number of secondary nerves on each side of midrib (15-)17-18, (versus (7-)9-14(-17); stems with lenticels brown, concolorous and inconspicuous, (versus discolorous, bright white and conspicuous), ovary bilocular (versus trilocular).Typus: Cameroon, Mt Oku and the Ijim Ridge, Aboh to Tum, $2400 \mathrm{~m}$ alt., fl. 22 Nov. 1996, Etuge 3600 (holotype K000337729! Fig. 2, isotypes MO!, WAG0336084!, WAG0336083!, YA0057050!);

Deinbollia cf. pinnata Schum. \& Thonn., sensu Cheek, in Cheek et al., (2000:162). 
264 Deinbollia sp. 2 sensu Cheek in Harvey et al., (2004: 125); Cheek \& Etuge in Cheek et al.,

265

266

267

268

269

270

271

272

273

274

275

276

277

278

279

280

281

282

283

284

285

286

287

288

289

290

291

292

293

294

295

296

297

298

299

300

301

302

303

304

305

306

307

308

309
(2004: 399); Cheek in Cheek et al., (2010: 143, fig 23).

Deinbollia sp. Chapman \& Chapman (Chapman \& Chapman, 2001: c41)

Monoecious tree or treelet (4-)5-15 m tall, trunk $14.5-40 \mathrm{~cm}$ diameter at $1.3 \mathrm{~m}$ from the ground, lacking exudate or scent when wounded, sparingly branched, nearly glabrous, apart from the inflorescence. Stems of flowering branches terete (0.8-) $1-1.5 \mathrm{~cm}$ diameter, solid (not hollow), second internode below apical inflorescence $2-2.5 \mathrm{~cm}$ long, outer epidermis pale grey-brown, contrasting with the darker brown bases of the adjoining petiolar pulvini, lenticels dense, raised, elliptic, $0.6-1.1 \mathrm{~mm}$ long, concolorous, inconspicuous, glabrescent, hairs sparse to dense, dark brown, cylindric $0.1-0.5 \mathrm{~mm}$ long.

Leaves alternate, pinnately compound, (14-)60-70 cm long; leaflets (4-)16-23 per leaf on flowering stems, leaflets 10-14 per leaf on leaves of juvenile trees. Petiole (4-)9.5-20.8 cm long, terete, c. $4 \mathrm{~mm}$ diameter at midpoint, drying pale yellow; basal pulvini dark brown; rhachis (4.5)32-44 cm long, (2-)8-11-jugate on flowering stems, 5-7-jugate on non-flowering stems of juvenile trees, the upper surface of the distal half flattened with two thin lateral wings and with a central dark hairy rounded central ridge, the rest of the rhachis glabrescent with sparse inconspicuous hairs (de Wilde 4555), or with sparse dark brown appressed hairs (Cable 3386). Leaflets mostly oblong (6.6-)14-19.5 x (2.1-)2.5-4 cm, (but leaflets of sterile branches to 6.5 $\mathrm{cm}$ wide), acumen c. $1 \mathrm{~cm}$ long, base broadly acute, slightly asymmetric, (basalmost leaflets lanceolate and about half the length of the other leaflets) lateral nerves and midrib yellow, raised above and below, convex, (15-)17-18 on each side of the midrib, nearly brochidodromous, the lateral nerve apices forming a weak irregular submarginal nerve, stronger branches uniting with the secondary nerve above, intersecondary nerves strong, parallel to the secondaries, tertiary and quaternary nerves reticulate raised yellow and conspicuous, on both surfaces, contrasting with the pale grey-green areolae (except in Cable $3386(\mathrm{~K})$ where they are concolorous and so inconspicuous above, possibly an artefact of poor drying); upper surface glabrous, lower surface with inconspicuous, minute, cylindrical, subappressed glossy dark-brown hairs c. $0.25 \mathrm{~mm}$ long, distributed very sparsely along the midrib and secondary nerves, absent from mature leaves of non-flowering specimens (e.g. Cheek 8709) but then the same hair type present on axillary buds and young leaves; petiolules yellow, $2-5 \mathrm{~mm}$ long, glabrous.

Inflorescence a 80-120-flowered, loose, terminal panicle $25 \times 10 \mathrm{~cm}$; auxiliary inflorescences sometimes present in the axils of the distal 1-4 leaves (Cheek 13625); peduncle of terminal inflorescences $0-2 \mathrm{~cm}$ long; rhachis internodes (1-)2-3 cm long, shortest in the distal portion; first order bracts caducous; indumentum brown hairy; primary branches 10-20 per inflorescence, $2-8 \mathrm{~cm}$ long, each bearing (1-)2-5 partial-inflorescences; partial-peduncles $0-5$ $\mathrm{mm}$ long, apex with a cluster of 3-5 bracteoles; bracteoles subulate to narrowly lanceolate, 2-3 $\mathrm{mm}$ long, apex narrowly acute, partial-inflorescences (1-)3-flowered in glomerules, pedicels erect, terete, $3-4 \times 1.5 \mathrm{~mm}$ (female), $4-5 \times 1 \mathrm{~mm}$ (male), sparsely puberulent, hairs $0.1-0.5 \mathrm{~mm}$ long.

Peer] reviewing PDF | (2020:10:54299:2:0:NEW 5 Feb 2021) 
310 Flowers white, scent not recorded, flower buds c. $4 \mathrm{~mm}$ diam., open flowers c. 6 x $7 \mathrm{~mm}$. Calyx

311 with sepals 5(-6), orbicular to broadly ovate, concave, green colour, 4-5 x 3.5-4.5 mm apex

312 obtuse. Corolla apex slightly exserted from calyx, petals rhombic or spatulate. Male flowers

313 (Fig. 1C). Petals 5(-6), white, rhombic c. $5 \times 3 \mathrm{~mm}$, apex obtuse-acute, base cuneate, margins

314 densely ciliate, hairs $0.3 \mathrm{~mm}$ long, outer surface glabrous, inner surface glabrous in distal half,

315 proximal half compressed funneliform with ventral appendage adnate at margins, retuse

316 (notched) for $0.5 \mathrm{~mm}$ at midline, adaxial surface moderately densely hairy, hairs c. $0.3 \mathrm{~mm}$ long.

317 Extra-staminal disc torus-like, glabrous, irregular, outer wall convex, lacking constrictions or

318 teeth with c. 15 poorly defined lobes, $2.5-3 \mathrm{~mm}$ wide, c. $0.8 \mathrm{~mm}$ high. Stamens c. 15, erect,

319 slightly exserted by $1-2 \mathrm{~mm}$ at anthesis, c. 5-6.5 mm long; filament 4-5 $\mathrm{mm}$ long, straight,

320 densely puberulent the entire length (Fig. 1D); anthers yellow, ovate-ellipsoid, 1-1.3 mm long.

321 Ovary (vestigial, Fig. 1E) bilobed, c. 1 x $1.5 \mathrm{~mm}$ densely appressed hairy, hairs c. $0.5 \mathrm{~mm}$; style

$3220.7 \mathrm{~mm}$ long, glabrous.

323

324

325

326

327

328

329

330

331

332

333

334

335

336

337

338

339

Female flowers (Fig. 1G), with sepals and petals as the male flowers, but petals c. 6 × 2.6-2.9 $\mathrm{mm}$, usually detaching with a stamen attached, probably due to interlocking hairs (see Fig. $1 \mathrm{~J}$ ), proximal two-thirds claw-like, c. $0.7 \mathrm{~mm}$ wide, margin sparsely and irregularly ciliate; ventral appendage with apex deeply bilobed, lobes c. $1 \mathrm{~mm}$ x $1 \mathrm{~mm}$; disc as in male flower. Stamens c. 10 (see Fig. 1I), included at anthesis, filament c. $2.5 \mathrm{~mm}$ long, proximal half to quarter glabrous, distal part densely hairy; anther as male flowers but indehiscent; ovary bilobed (see Fig. $1 \mathrm{H}$ ), $3.2 \times 5 \mathrm{~mm}$, indumentum as male flower, style c. $5 \mathrm{~mm}$ long, apical $1 \mathrm{~mm}$, curved, surface papillate-minutely puberulent, apex subcapitate. Infructescence, of same dimensions as inflorescence, erect. Fruit colour recorded as nearly black when ripe, tasting sweet-sour (Elisha Barde, see uses below), and not coloured yellow when ripe (as in other species of the genus), mericarps 1 or 2, transversely ellipsoid, c. $1.8 \times 2.1 \times 1.2 \mathrm{~cm}$ (hydrated), the surface leathery, shallowly and finely muricated, glabrous, mesocarp spongy and juicy, 1-seeded. Seed ellipsoid, c. $1.8 \times 1.1 \times 0.8 \mathrm{~cm}$, testa thin, parchment like, endosperm absent, cotyledons fleshy.

Phenology: flowering in November-December; fruiting in February and April, immature fruit recorded in December and June.

340

341

342

343

344

345

346

347

348

349

350

351

352

353

Local name and uses: none are reported in Cameroon but in Ngel Nyaki, Nigeria, Elisha Emmanuel Barde of the Nigeria Montane Forest Project (pers. comm. to M. Cheek Dec. 2020), states that Nyeberehi (Fulfude) is the general name for all Deinbollia species while Jellahi (Fulfude) is a specific name for Deinbollia onanae in Ngel Nyaki where Fulfude speakers (Fulanis) use the bark of this species as medicine for themselves, to treat stomach aches as well as an anti-helminthic. It is not used for treating cattle. The fruits are reported to taste sour-sweet by Mr Barde. The species is also known as Pabba (Ndolla language).

Etymology: The specific epithet of Deinbollia onanae means 'of Onana' commemorating Dr Jean-Michel Onana, currently Senior Lecturer in Botany at the University of Yaoundé I, Cameroon, champion of plant conservation in Cameroon, specialist in Sapindales (Burseraceae, author of Flore du Cameroun Burseraceae (Onana, 2017), co-chair of the IUCN Central African Red List Authority for Plants, former Head of the National Herbarium of Cameroon (2005- 
354

355

356

357

358

359

360

361

362

363

364

365

366

367

368

369

370

371

372

373

374

375

376

377

378

379

380

381

382

383

384

385

386

387

388

389

390

391

392

393

394

395

396

397

398

399

2016), co-author of the Red Data Book of the Plants of Cameroon (Onana \& Cheek, 2011) and the Taxonomic Checklist of the Vascular Plants of Cameroon (Onana, 2011). He led field teams of YA staff working with those of $\mathrm{K}$ that resulted in the collection of several of the specimens of this species and personally collected this species in the field (Onana 1600, K, YA).

Distribution \& ecology: known only from the Cameroon Highlands of Cameroon (one location in the adjoining Mambilla Plateau, Nigeria) Fig. 3. Upper submontane \& montane evergreen forest, sometimes in gallery forest; (1200-)2050-2200 m alt.

Additional specimens: CAMEROON. South West Region, Mt Kupe, near main summit, immature fr., 26 June 1996, Cable 3386 (K000197863!, YA!);_North West Region. Bali Ngemba Forest Reserve, fr. April 2002, Onana 1600 (YA!); Mt Oku and the Ijim Ridge: above Laikom, st. 21 Nov..1996, Cheek 8709 (K000337728! YA!); Dom, Kinjinjang Rock, st. 25 Sept. 2006, Cheek 13436 (K000580433!; YA!); ibid. Forest Patch 1, fl. buds, 27 Sept. 2006, Cheek 13625 (K000580434!, MO!,US!, YA!); ibid., Javelong Forest, st. 29 April 2005, Pollard 1400 (K000580432!; YA!); Adamaoua Region, c. 120 km E of Ngaoundéré, $15 \mathrm{~km}$ NE of Belel, falls in Koudini River, alt. $\pm 1200 \mathrm{~m}$, fl. 4 Dec. 1964, W.J.J.O. \& J.J.F.E. de Wilde, B.E.E. de Wilde-Duyfjes 4555 (K000593309!; K000593310!, WAG1269760! , YA). NIGERIA.

Taraba State, Mambilla Plateau, Ngel Nyaki Forest Reserve, near camp, fr. 2 Dec. 2003, H.M. Chapman 481 (FHI, K!); ibid. female fl. 4 Dec. 2002, H.M. Chapman 484 (FHI, K!).

Notes: Deinbollia onanae first came to our attention in 2000 when completing the "Plants of Kilum-Ijim" (Cheek et al., 2000). Two specimens of Deinbollia matched no other and were named Deinbollia cf. pinnata (Cheek et al., 2000). In subsequent surveys this taxon was more explicitly referred to as a new species: Deinbollia sp. 2 (Harvey et al., 2004, Cheek et al., 2004, Cheek et al., 2009). However, the earliest known collection was made in 1964 (W.J.J.O. \& J.J.F.E. de Wilde, de Wilde-Duyfjes 4555(K)).

This species is remarkable for the very large number of pairs of unusually long and slender leaflets (Fig. 4), and for the comparatively large size of the individuals which often attain 10-15 $\mathrm{m}$ in height (Fig. 4), among the largest trees known in the genus. However, at Ngel Nyaki trees can begin flowering at only $2.5 \mathrm{~m}$ in height (E. Barde pers. comm. to Cheek Jan. 2020)

Conservation: Deinbollia onanae is rare at each of its six known locations so far as is known, although at Ngel Nyaki this is difficult to establish due to potential confusion with Deinbollia oreophila. Despite many thousands of herbarium specimens being collected at Kilum-Ijim, at Mt Kupe and the Bakossi Mts, at Ngel Nyaki and at Bali Ngemba (Cheek et al., 2000; Cheek et al., 2004; Harvey et al., 2006) only two specimens of this species at two sites, were made at each of the first three locations and only one at the third location. Surveys at other sites with suitable habitat in the Cameroon Highlands and elsewhere, e.g at Mt Cameroon and at the Lebialem Highlands, failed to find this species (Cheek et al., 1996; Cable \& Cheek 1998; Harvey et al., 2010; Cheek et al., 2011). However, at Dom, where a targetted search for this species was made by the first author, three specimens were made, each representing single, isolated trees (Cheek et al., 2010). No more individuals than these were found. At Adamaoua Region, Cameroon it has only been collected once, and only a single tree was then noted (W.J.J.O. \& J.J.F.E. de Wilde,

Peer] reviewing PDF | (2020:10:54299:2:0:NEW 5 Feb 2021) 
400

401

402

403

404

405

406

407

408

409

410

411

412

413

414

415

416

417

418

419

420

421

422

423

424

425

426

427

428

429

430

431

432

433

434

435

436

437

438

439

440

441

442 Detailed information on the ecology of Deinbollia onanae (under the name D. pinnata) is 443

444

B.E.E. de Wilde-Duyfjes $4555(\mathrm{~K})$ ). None of these locations is formally protected for nature conservation. Tree cutting for timber and habitat clearance for agriculture has long been known to be a threat at all but the last of these locations (references cited above). The range of the species is large: extent of occurrence was calculated as $50,525 \mathrm{~km}^{2}$ using GeoCAT. However, severe habitat fragmentation has resulted over many hundreds of years, forest patches being now distant from each other by tens of kilometres, isolated in oceans of cultivation and secondary fire-maintained grassland making the possibility of primate-mediated dispersal from one forest area to another now extremely unlikely. Ecological evidence from Ngel Nyaki is that while Deinbollia regenerates in that forest patch, its primate dispersers do not, or seldom cross to other forest patches (Dutton \& Chapman, 2014, see discussion below). We assess the area of occupancy of Deinbollia onanae as $34 \mathrm{~km}^{2}$ using the IUCN preferred $4 \mathrm{~km}^{2}$ cell size. Therefore, we assess this species as Endangered, EN B2ab(iii) using the IUCN (2012) standard. We suggest that this species be included in forest restoration plantings within its natural range to partly reverse its move to extinction. However, the large (c. $1 \mathrm{~cm}$ diam.), thin-walled seeds are probably recalcitrant, so not suitable for conventional seed-banking, and should not be allowed to be dried before sowing since this can be expected to kill them. Experience at Ngel Nyaki (Matthesius et al., 2011) shows that it is possible to raise hundreds of seedlings in nurseries and to establish them in natural forest.

\section{DISCUSSION}

The discovery of a threatened, new species to science from surviving natural habitat in the Cameroon Highlands is not unusual. At most of the six locations from which we here describe Deinbollia onanae, additional new or resurrected species to science, all highly localised, rangerestricted and threatened with extinction, have been documented in recent years. At Ngel Nyaki in Nigeria a point endemic Memecylon species (H.M. Chapman 744) as yet undescribed is present (pers. comm. R.D. Stone to Hazel Chapman), while at Mt Kupe for example, Coffea montekupensis Stoffelen (Stoffelen et al., 1997) and more recently the new species and genus to science Kupeantha kupensis Cheek \& Sonké (Cheek et al., 2018a). At Bali Ngemba, Leptonychia kamerunensis Engler \& K. Krause (Cheek et al., 2013), Psychotria babatwoensis Cheek (Cheek et al., 2009) and Allophylus ujori Cheek (Cheek \& Etuge, 2009b), at Mt Oku and the Ijim Ridge Kniphofia reflexa Marais (Maisels et al., 2000), Scleria cheekii Bauters (Bauters et al., 2018), while at Dom, the endemic epiphytic sedge Coleochloa domensis Musaya \& D.A Simpson (Muasya et al., 2010). No additional such new species are known from the Adamaoua location, probably because it is less completely sampled than the preceeding four.

However, Deinbollia onanae is exceptional among these aforementioned species in that it is a new species of tree predominantly of montane forest. The many other newly discovered for science, resurrected or rediscovered plant species of the Cameroon Highlands have been overwhelmingly either been herbs or shrubs or are derived from submontane habitats (800-2000 m altitude).

available from several studies led by Hazel Chapman at Ngel Nyaki, the largest or one of the largest, surviving forests in the Mambilla Plateau, a branch of the Cameroon Highlands that 
445 extends into Nigeria (see map, Fig. 3). At this submontane forest patch, area c.5.7 km², 1588

4461690 m altitude, Deinbollia (Fig. 4) is recorded as one of the 20 most abundant woody plant

447 species, with 158.68 stems above $1 \mathrm{~cm}$ diam. per ha (Abiem et al., 2020). In contrast, the 1970s 1

448 ha enumeration plot at Ngel Nyaki (Chapman \& Chapman, 2001: 25-26) yielded five stems of

449 "Deinbollia sp." in the C strata (understorey trees 7-13 $\mathrm{m}$ high) with diameter at $1.3 \mathrm{~m}$ above the

450 ground exceeding $14.5 \mathrm{~cm}$, of which two exceeded $28 \mathrm{~cm}$ and one $40 \mathrm{~cm}$. This is more consistent

451 with frequencies observed in Cameroon for Deinbollia onanae. The explanation between the

452 disparity in stem numbers per ha between these two studies is probably that there is high

453 mortality of juveniles of Deinbollia onanae at Ngel Nyaki, few surviving to make $14.5 \mathrm{~cm}$

454 diameter or more trees recorded in the second study. We speculate that an alternative

455 explanation may be that the numerous small diameter individuals recorded by Abiem et al.

456 (2020) may not be the usually infrequent $D$. onanae, but the similar but much smaller $(0.8-3(-5)$

$457 \mathrm{~m}$ tall) $D$. oreophila which at this altitude, over the border in Cameroon, is vastly more frequent

458 in submontane forest (Cheek \& Etuge, 2009). Many of the observations of animals e.g. putty-

459 nosed monkeys (Cercopithecus nictitans) feeding on Deinbollia at Ngel Nyaki (Gawaisa, 2010)

460 were of primates in the crowns of trees so more likely to be of the larger, less frequent $D$. onanae

461 which is evidenced at this location by two herbarium specimens (see "additional specimens"

462 below) while $D$. oreophila has not yet been so recorded (and so may not in fact be present).

463 Studies on the dietary preferences of the rare Nigerian to Cameroon chimpanzee (Pan

464 troglodytes ellioti) by Dutton \& Chapman (2014) at Ngel Nyaki found that among the 52 plant

465 species consumed mainly as fruit, Deinbollia was the $4^{\text {th }}$ (wet season) or $5^{\text {th }}$ (dry season) species

466 preferred of the 17 tree species over $10 \mathrm{~cm}$ diameter at breast height that were identified as seeds

467 from 495 fecal samples. This record is certainly $D$. onanae since $D$. oreophila does not form

468 trunks of such large diameters (Cheek \& Etuge, 2009). However, Deinbollia was found in only

469 one of these fecal samples, in which 47 of its seeds were recorded, collected in February 2011

470 (Dutton \& Chapman, 2014). Only 16 weaned individuals of chimpanzee are known at Ngel

471 Nyaki. More numerous and so probably more effective at seed dispersal are putty-nosed

472 monkeys (Cercopithecus nictitans). Gawaisa (2010) reported that at Ngel Nyaki Deinbollia fruit

473 ranked third in preferred species of fruits of $C$. nictitans during February and March, and fifth in

474 January. Hutchinson (2015) has shown that males in particular show a preference for Deinbollia

475 seeds in the rainy season (Hutchinson 2014). Seeds are both swallowed, passing through the gut

476 (average 2 per faecal sample) and sucked and spat by the putty-nosed monkeys (averaging 5

477 seeds per spitting event) (Chapman et al., 2010). An experiment comparing germination time

478 and success among Deinbollia seeds which had been defecated, spat and hand-cleaned found that

479 gut passage had a significant beneficial effect on germination rates. A higher proportion of

480 defecated seeds (60-70\%) germinated than spat (c. 40\%) or hand-cleaned (c.35\%) seeds, and the

481

482

483

484

485

486

487

488

489

490 defecated seeds germinated on average a few days earlier than non-defecated seeds (Chapman et al., 2010). In addition, leaves but not fruit of Deinbollia have been recorded as being consumed by tantalus monkeys (Chlorocebus tantalus tantalus), but only in very low quantities (Agmen et al., 2010). Putty nose monkeys also eat the leaves and flowers of Deinbollia (Gawaisa, 2010; Hutchinson, 2015). Studies of dispersal of seeds of about 40 Ngel Nyaki forest species up to 30 $\mathrm{m}$ into grassland from the forest edge using seed traps showed that Deinbollia was one of the small number of forest species that do not disperse seeds out of the forest, but that within forest, natural regeneration from seed does occur. The species has been classified as a shade-bearer and is not a pioneer (Barnes \& Chapman, 2014). Deinbollia "pinnata" was one of three species of tree used to test the Janzen-Connell hypothesis at this site. Five hundred and seventy seedlings 
491

492

493

494

495

496

497

498

499

500

501

502

503

504

505

506

507

508

509

510

511

512

513

514

515

516

517

518

519

520

521

522

523

524

525

526

527

528

529

530

531

532

533

534

535

536

were raised and planted at distances of up to $25 \mathrm{~m}$ from 19 mature conspecific "mother" trees and monitored over the three months of the study. Predation was significantly higher closer to the mother trees than distant from them (c. 30\% vs. 20\%), but there was no support for JanzenConnell effects in seedling height growth. About $80 \%$ of the seedlings survived, and they grew 4.5-5.5 cm over the 3 months (Matthesius et al., 2011). Deinbollia "pinnata" is one of 28 identified tree species used by chimpanzees as nesting trees at Ngel Nyaki, but is not among the preferred top five (Dutton et al., 2016).

\section{Montane Forest Trees of the Cameroon Highlands}

The Cameroon Highlands extend through four tropical African countries. Beginning in the south on the volcano island of Bioko (Equatorial Guinea) they continue on the mainland with the Mount Cameroon active volcano, heading NNE along a major fault, forming the ridges, plateaux and isolated peaks of the Bakossi Mts and Mt Kupe, Muanenguba, Bamboutos Mts, the Lebialem and Bamenda Highlands, Mt Oku, Tchabal Mbabo, then heading eastwards and forming the lower and drier Adamaoua Highlands which extend into the Central African Republic. Two westward extending arms from the central section in Cameroon extend into Nigeria, forming the Obudu and Mambilla Plateaux. The altitudinal division between montane and submontane forest is well-marked in the Cameroon Highlands. Most species of montane tree only occur above the $2000 \mathrm{~m}$ contour and not below it (Table 3), while tree species from the submontane forest belt rarely exceed the $2000 \mathrm{~m}$ contour (Cheek et al., 1996; Cheek et al., 2000; Cheek et al., 2004), although some species of tree, like Deinbollia onanae can occur on either side of the $2000 \mathrm{~m}$ contour. Since most of the Cameroon Highlands do not ascend above $2000 \mathrm{~m}$ alt., montane forest is not ubiquitous along their length. Moreover, even where altitude is sufficient to support it and where it formerly occurred, montane forest has seen massive clearance for agriculture, and has been totally lost at the Bamboutos Mountains of West Region Cameroon (Ngoufou, 1992). Indeed, the Bamenda Highlands of Cameroon, long since cleared of their montane forest, are now known in Cameroon as "The grasslands" because they are blanketed in secondary grassland, perpetuated by fire. It has been estimated that as much as $96.5 \%$ of the original montane forest of the Bamenda Highlands has been lost (Cheek et al., 2000: 49-50). The tallest mountain in the range, Mt Cameroon $(4040 \mathrm{~m})$, despite its height and lack of human activity above $2000 \mathrm{~m}$ alt., has surprisingly little forest above this contour due to the free-draining nature of its predominantly volcanic cinder substrate (Thomas \& Cheek, 1992; Cheek et al., 1996; Cable \& Cheek, 1998). The single largest block of montane forest that survives by far in the Cameroon Highlands is that at Mt Oku and the Ijim Ridge (Kilum-Ijim) where about $70 \mathrm{~km}^{2}$ has been estimated to survive and to have a measure of protection. Here it extends from the $2000 \mathrm{~m}$ contour to the summit at $3011 \mathrm{~m}$ alt. (Cheek et al., 2000: 20). Elsewhere in the Cameroon Highlands, such as at Mt Kupe, Muanenguba, Bali-Ngemba, Ngel Nyaki and Dom, surviving patches of montane forest consists of only a few hectares, although an area of $40 \mathrm{~km}^{2}$ of forest has been recorded at Dutsin Dodo and Gangirwal mountain within the Gashaka Gumti National Park of Nigeria (H.M. Chapman pers. obs. 2000)

The tree species diversity of the montane forest of the Cameroon Highlands is low (28 species, based on herbarium specimens, see Table 3) compared with submontane forest which has hundreds of species, and also in great contrast, montane forest contains few Cameroon Highland

Peer] reviewing PDF | (2020:10:54299:2:0:NEW 5 Feb 2021) 
537

538

539

540

541

542

543

544

545

546

547

548

549

550

551

552

553

554

555

556

557

558

559

560

561

562

563

564

565

566

567

568

569

570

571

572

573

574

575

576

577

578

579

580

581

582

endemic tree species (only seven: $25 \%$ of the total, see Table 3 ). The majority of the canopy contains even fewer species. It was estimated that just ten species made up $90 \%$ of the montane forest canopy at Mt Oku and the Ijim Ridge, three of which are endemics (Cheek et al., 2000:20). The majority of montane tree species of the Cameroon Highlands are widespread in montane forest in Africa (Afromontane) occurring also east of the Congo Basin in the rift mountains of East Africa and several, such as Ilex mitis, extend north to Ethiopia and south to South Africa. The East African montane forest is more species-diverse, and only a subset of its species extend west to the Cameroon Highlands, and an even smaller subset, just seven species, extend even further west from the Cameroon Highlands, to the Guinea Highlands (Couch et al., 2019:54).

The high altitudinal range of Deinbollia onanae is unrivalled west of the Congo basin by any other species of the genus. Elsewhere in Africa it is matched only by Deinbollia kilimandscharica Taub., of mountains from Ethiopia to Malawi, reported to achieve $2250 \mathrm{~m}$ elevation in Tanzania (Davies \& Verdcourt, 1998). Most species of the genus in tropical Africa are lowland forest shrubs, in the Cameroon Highlands only Deinbollia oreophila also occurs regularly at altitude over $800 \mathrm{~m}$, and is largely confined to the submontane forest band being recorded from (880-)1000-1900(-2050) $\mathrm{m}$ altitude where it is often relatively frequent (Cheek \& Etuge, 2009). We postulate based on their shared morphological characters that these two may be sister species (see results above) that have segregated between two adjacent altitudinally based vegetation types in a similar way to certain clades of bird species in the Cameroon Highlands such as the Turaco (Njabo \& Sorensen, 2009). This hypothesis needs testing. It would most readily done by a comprehensive species-level molecular phylogenomic study of Deinbollia as has been achieved in several other genera, such as Nepenthes L.f. (Murphy et al., 2020).

The fruits of Deinbollia onanae are similar to those of other species of the genus, i.e., fleshy, indehiscent and large-seeded, suggesting that the now intermittent distribution of this species, along a line c. $570 \mathrm{~km}$ along peaks of the Cameroon Highland line, was likely due to dispersal in the gut by animals. Chimpanzees (Pan troglodytes ellioti) and putty-nose monkeys

(Cercopithecus nictitans) are known to disperse the species at one location however these species do not cross from one forest patch to another, especially when as now these patches can be separated by tens of kilometres of secondary grassland. Formerly the range of Deinbollia onanae may have once been more continuous along the mountain range than today, but it was likely greatly reduced when forest was cleared for agriculture as reported above.

\section{CONCLUSIONS}

Such cases as Deinbollia onanae underline the urgency for publishing further discoveries while species still survive, since threats to such rare species are often clear and current, putting these species at high risk of extinction. About 2000 new species of vascular plant have been discovered by science each year for the last decade or more (Cheek et al., 2020). Until species are delimited and known to science, it is more difficult to assess them for their conservation 
583

584

585

586

587

588

589

590

591

592

593

594

595

596

597

598

599

600

601

602

603

604

605

606

607

608

609

610

611

612

\section{3}

614

615

616

617

618

619

620

621

622

623

624

status and so the possibility of protecting them is reduced (Cheek et al., 2020). Documented extinctions of plant species are increasing, e.g. Oxygyne triandra Schltr. of Cameroon is now known to be globally extinct (Cheek et al., 2018b) as is Afrothismia pachyantha Schltr. (Cheek et al., 2019). In some cases species appear to be extinct even before they are known to science, such as Vepris bali Cheek, once sympatric with Deinbollia onanae at Bali Ngemba (Cheek et al., 2018c), and elsewhere, Nepenthes maximoides Cheek (King \& Cheek, 2020). Most of the $>800$ Cameroonian species in the Red Data Book for the plants of Cameroon are threatened with extinction due to habitat clearance or degradation, especially of forest for small-holder and plantation agriculture e.g. oil palm, following logging (Onana \& Cheek, 2011). Efforts are now being made to delimit the highest priority areas in Cameroon for plant conservation as Tropical Important Plant Areas (TIPAs) using the revised IPA criteria set out in Darbyshire et al., (2017). This is intended to help avoid the global extinction of additional endemic species such as the Endangered Deinbollia onanae which will be included in the proposed IPA s of Mt Kupe, Bali Ngemba, Kilum-Ijim and Dom.

\section{Acknowledgements}

Most of the specimens cited in this paper were collected with the support of volunteers of Earthwatch Europe, Oxford and by our colleagues Kenneth Tah, Olivier Sene, Victor Nana, Verina Ingram, David Okebiro, Assefa, B. Gapta, H. Ndue, M. Kissimou, Rene Nfon, Stuart Cable, Ben Pollard and the late Martin Etuge. Drs Florence Ngo Ngwe, Eric Nana, Jean Betti Lagarde, the current and former directors, of IRAD-National Herbarium of Cameroon, Yaoundé, and their staff are thanked for expediting the collaboration between our two institutes. Nigerian specimens were obtained thanks to the Nigerian Montane Forest Project. Janis Shillito typed the manuscript. Xander van der Burgt made the map and the photo of the type specimen, and brought to light the overlooked Nigerian records. Emmanuel Barde Elisha of the Nigerian Montane Forests project helped provide information on local names and uses at Ngel Nyaki. Roy Gereau and David Kenfack are thanked for constructively reviewing an earlier version of this paper.

\section{REFERENCES}

Abiem I, Arellano G, Kenfack D, Chapman H. 2020. Afromontane Forest Diversity and the Role of Grassland-Forest Transition in Tree Species Distribution. Diversity. 12(1):30.

Agmen FL, Chapman HM, Bawuro M. 2010. Seed dispersal by tantalus monkeys (Chlorocebus tantalus tantalus) in a Nigerian montane forest. African Journal of Ecology 48(4):1123-8.

Bachman S, Moat J, Hill AW, de la Torre J, Scott B. 2011. Supporting Red List threat assessments with GeoCAT: geospatial conservation assessment tool, in: Smith V, Penev, eds. eInfrastructures for data publishing in biodiversity science. ZooKeys 150: 117-126. Available from: http://geocat.kew.org/ [accessed 19 July 2020].

Barnes AD, Chapman HM. 2014. Dispersal traits determine passive restoration trajectory of a Nigerian montane forest. Acta oecologica. 56:32-40. 
625

626

627

628

629

630

631

632

633

634

635

636

637

638

639

640

641

642

643

644

645

646

647

648

649

650

651

652

653

654

655

656

657

658

659

660

661

662

663

664

665

666

667

668

669

Barthlott W, Lauer W, Placke A. 1996. Global distribution of species diversity in vascular plants: towards a world map of phytodiversity. Erkunde 50: 317-328 (with supplement and figure).

Bauters K, Goetghebeur P, Larridon I. 2018. Scleria cheekii, a new species of Scleria subgenus Hypoporum (Cyperaceae, Cyperoideae, Sclerieae) from Cameroon. Kew Bulletin 73, 27. https://doi.org/10.1007/s12225-018-9752-7

Buerki S, Forest F, Acevedo-Rodriguez P, Callmander MW, Nylander JA, Harrington M, Sanmartin I, Kuepfer P, Alvarez N. 2009. Plastid and nuclear DNA markers reveal intricate relationships at subfamilial and tribal levels in the soapberry family (Sapindaceae). Molecular Phylogenetics and Evolution 51(2):238-58.

Buerki S, Lowry II PP, Alvarez N, Razafimandimbison SG, Küpfer P, Callmander MW. 2010. Phylogeny and circumscription of Sapindaceae revisited: molecular sequence data, morphology and biogeography support recognition of a new family, Xanthoceraceae. Plant Ecology and Evolution. 143(2):148-59.

Burkill HM. 2000. The Useful Plants of West Tropical Africa. Vol. 5, families S-Z. Royal Botanic Gardens, Kew.

Cable S, Cheek M. 1998. The plants of Mt Cameroon, a conservation checklist. Kew: Royal Botanic Gardens.

Chapman J, Chapman H. 2001. The Forests of Taraba and Adamawa States, Nigeria an Ecological Account and Plant Species Checklist. University of Canterbury: Christchurch, New Zealand. pp. 221.

Chapman HM, Goldson SL, Beck J. 2010. Postdispersal removal and germination of seed dispersed by Cercopithecus nictitans in a West African montane forest. Folia primatologica. 81(1):41-50.

Cheek M. 2004. Deinbollia maxima. The IUCN Red List of Threatened Species 2004: e.T46178A11033700. https://dx.doi.org/10.2305/IUCN.UK.2004.RLTS.T46178A11033700.en. Downloaded on 21 November 2020.

Cheek M. 2017a. Deinbollia angustifolia. The IUCN Red List of Threatened Species 2017:

e.T110084840A110084842. https://dx.doi.org/10.2305/IUCN.UK.20173.RLTS.T110084840A110084842.en. Downloaded on 21 November 2020.

Cheek M. 2017b. Deinbollia macrantha. The IUCN Red List of Threatened Species 2017:

e.T110084898A110084900. https://dx.doi.org/10.2305/IUCN.UK.20173.RLTS.T110084898A110084900.en. Downloaded on 21 November 2020.

Peer) reviewing PDF | (2020:10:54299:2:0:NEW 5 Feb 2021) 
670 Cheek M, Cable S. 1997. Plant Inventory for conservation management: the Kew-Earthwatch

671 programme in Western Cameroon, 1993-96, pp. 29-38 in Doolan, S. (Ed.) African Rainforests

672 and the Conservation of Biodiversity, Oxford: Earthwatch Europe.

673

674

Cheek M, Etuge M. 2009a. A new submontane species of Deinbollia (Sapindaceae) from

675 Western Cameroon and adjoining Nigeria. Kew Bulletin 64(3): 503-508.

676

677

678

679 https://doi.org/10.1007/s12225-009-9132-4

Cheek M, Etuge M. 2009b. Allophylus conraui (Sapindaceae) reassessed and Allophylus ujori described from western Cameroon. Kew Bulletin 64(3): 495-502.

680

681

682

683

684

Cheek M, Ngolan R. 2007. A reassessment of the Dovyalis spinosissima Gilg (Flacourtiaceae) complex in Africa, with a new species from Cameroon. Kew Bulletin 61: 595-600.

http://www.jstor.org/stable/20443304

686

Cheek M, Alvarez-Agiurre MG, Grall A, Sonké B, Howes M-JR, Larridon L. 2018a.

687

Kupeantha (Coffeeae, Rubiaceae), a new genus from Cameroon and Equatorial Guinea. PLoS ONE 13: 20199324. https://doi.org/10.1371/journal.pone.0199324

688

689

Cheek M, Arcate J, Choung S, Herian K, Corcoran M, Horwath A. 2013. Three new or

690 resurrected species of Leptonychia (Sterculiaceae-Byttneriaceae-Malvaceae) from West-Central Africa. Kew Bulletin 68: 579-90. http://dx.doi.org/10.1007/s12225-013-9469-6 )

692 Cheek, M, S Cable, FN Hepper, N Ndam \& J Watts. 1996. Mapping plant biodiversity on Mt. 693 Cameroon. pp. 110-120 in van der Maesen, van der Burgt \& van Medenbach de Rooy (Eds), The https://doi.org/10.1007/s12225-008-9056-4

699

Cheek M, Etuge M, Williams S. 2019. Afrothismia kupensis sp. nov. (Thismiaceae), Critically Endangered, with observations on its pollination and notes on the endemics of Mt Kupe, Cameroon. Blumea - Biodiversity, Evolution and Biogeography of Plants. 64(1): 158-164 https://doi:10.3767/blumea.2019.64.02.06

Cheek M, Gosline G, Onana JM. 2018c. Vepris bali (Rutaceae), a new critically endangered (possibly extinct) cloud forest tree species from Bali Ngemba, Cameroon. Willdenowia 48: 285 292. doi: https://doi.org/10.3372/wi.48.48207

710

Cheek M, Harvey Y, Onana JM. 2010. The plants of Dom, Bamenda Highlands, Cameroon, A Conservation Checklist, RBG, Kew, 162pp. 
712 Cheek M, Harvey Y, Onana JM. 2011. The Plants of Mefou Proposed National Park, Yaoundé,

713 Cameroon, A Conservation Checklist. Kew: Royal Botanic Gardens.

714

715 Cheek M, Mackinder B Gosline G, Onana J, Achoundong G. 2001. The phytogeography and

716 flora of western Cameroon and the Cross River-Sanaga River interval. Systematics and

717 Geography of Plants 71: 1097-1100. https://doi.org/10.2307/3668742

718

719

720

721

722

723

724

725

726

727

728

729

730

731

732

733

734

735

736

737

738

739

740

741

742

743

744

745

746

747

748

749

750

751

752

753

754

755

756

757

Cheek M, Nic Lughadha E, Kirk P, Lindon H, Carretero J, Looney B, Douglas B, Haelewaters D, Gaya E, Llewellyn T, Ainsworth M, Gafforov Y, Hyde K, Crous P, Hughes M, Walker BE, Forzza RC, Wong KM, Niskanen T. 2020. New scientific discoveries: plants and fungi. Plants, People Planet 2:371-388.

https://doi.org/10.1002/ppp3.10148

Cheek M, Onana J-M, Pollard BJ. 2000. The Plants of Mount Oku and the Ijim Ridge, Cameroon, a Conservation Checklist. Kew: Royal Botanic Gardens, 220 pp.

Cheek M, Pollard BJ, Darbyshire I, Onana J, Wild C. 2004. The plants of Kupe, Mwanenguba and the Bakossi Mountains, Cameroon. A conservation checklist. Kew: Royal Botanic Gardens.

Cheek M, Tchiengue B, Tacham WN. 2017. Ternstroemia cameroonensis (Ternstroemiaceae), a new medicinally important species of montane tree, nearly extinct in the Highlands of Cameroon. Blumea 62: 53 - 57. https://doi.org/10.3767/000651917X695362.

Cheek M, Tsukaya H, Rudall PJ, Suetsugu K. 2018c. Taxonomic monograph of Oxygyne (Thismiaceae), rare achlorophyllous mycoheterotrophs with strongly disjunct distribution. PeerJ 6:e4828https://doi.org/10.7717/peerj.4828

\section{Couch C, Cheek M, Haba PM, Molmou D, Williams J, Magassouba S, Doumbouya S,} Diallo YM. 2019. Threatened Habitats and Important Plant Areas (TIPAs) of Guinea, West Africa. Kew: Royal Botanic Gardens.

Darbyshire I, Anderson S, Asatryan A, et al., 2017. Important Plant Areas: revised selection criteria for a global approach to plant conservation. Biodiversity Conservation 26: 1767-1800. https://doi.org/10.1007/s10531-017-1336-6.

Davies FG, Verdcourt B. 1998. Sapindaceae. Flora of Tropical East Africa. Rotterdam: Balkema.

Dutton P, Chapman H. 2015. Dietary preferences of a submontane population of the rare Nigerian- Cameroon chimpanzee (Pan troglodytes ellioti) in Ngel Nyaki Forest Reserve, Nigeria. American journal of primatology. 77(1):86-97.

Dutton P, Moltchanova E, Chapman H. 2016. Nesting ecology of a small montane population of the Nigerian/Cameroon chimpanzee (Pan troglodytes ellioti) in Nigeria. Folia Primatologica 87(6):361-74. https://doi.org/10.1159/000454921 
758

759

760

761

762

763

764

765

766

767

768

769

770

771

772

773

774

775

776

777

778

779

780

781

782

783

784

785

786

787

788

789

790

791

792

793

794

795

796

797

798

799

800

801

802

803

Fouilloy R, Hallé N. 1973. Sapindacées. Flore du Cameroun 16. Paris: Museum National d'Histoire Naturelle.

Gawaisa GS. 2010. The Role of Putty Nose Monkey (in forest regeneration of a montane forest ecosystem of Ngel Nyaki forest reserve, Taraba State, Nigeria) (Linnaeus, 1766). PhD thesis Federal University of Technology, Yola, Nigeria/Nigerian Montane Forest Project.

Harvey Y, Pollard BJ, Darbyshire I, Onana JM, Cheek M. 2004. The plants of Bali Ngemba Forest Reserve, Cameroon. a conservation checklist. Kew: Royal Botanic Gardens.

Harvey YH, Tchiengue B, Cheek M. 2010. The plants of the Lebialem Highlands, a conservation checklist. Kew: Royal Botanic Gardens.

Hutchinson K. 2015. Diet of Cercopithecus nictitans and investigation into its potential to act as a surrogate disperser in disturbed Afromontane forests. MSc Thesis University of Canterbury,

New Zealand

IPNI. 2020. International Plant Names Index. The Royal Botanic Gardens, Kew, Harvard University Herbaria \& Libraries and Australian National Botanic Gardens. Available at http://www.ipni.org (accessed 05 June 2020).

IUCN. 2012. IUCN Red List Categories and Criteria: Version 3.1. Second edition. Gland, Switzerland and Cambridge, UK: IUCN. Available at http://www.iucnredlist.org/ (accessed: 07/2020).

JStor Global Plants. 2020. continuously updated) Available at http://plants.jstor.org/ (accessed 14 June 2020).

Keay RWJ. 1958. Sapindaceae, pp.709-725 in Keay (ed.) Flora of West Tropical Africa 1(2). London: Crown Agents.

Kenfack D. 2011. A synoptic revision of Carapa (Meliaceae). Harvard Papers in Botany 16(2), 171231. Retrieved November 7, 2020, from http://www.jstor.org/stable/41761712

Maisels FM, Cheek M, Wild C. 2000. Rare plants on Mt Oku summit, Cameroon. Oryx 34 (2): 136-140. https://doi.org/10.1017/s0030605300031057

Matthesius A, Chapman H, Kelly D. 2011. Testing for Janzen-Connell effects in a west African montane forest. Biotropica. 43(1):77-83.

Muasya MA, Harvey YH, Cheek M, Tah K, Simpson DA. 2010. A new species of epiphytic Coleochloa (Cyperaceae) from Cameroon. Kew Bulletin 65: 1-3 https://doi.org/10.1007/s12225010-9194-3

Peer] reviewing PDF | (2020:10:54299:2:0:NEW 5 Feb 2021) 
804

805

806

807

808

809

810

811

812

813

814

815

816

817

818

819

820

821

822

823

824

825

826

827

828

829

830

831

832

833

834

835

836

837

838

839

840

841

842

843

844

845

846

847

Ngoufou R. 1992. The Bamboutous Mountains: Environment and Rural Land Use in West

Cameroon. Mountain Research and Development 12(4): 349-356.

https://www.jstor.org/stable/3673685?seq=1\#metadata info tab contents

Nickrent DL, Costea M, Barcelona JF, Pelser PB, Nixon K. 2006

onwards. PhytoImages. Available from: http://www.phytoimages.siu.edu

Njabo KY, Sorenson MD. 2009. Origin of Bannerman's Turaco Tauraco bannermani in relation to historical climate change and the distribution of West African montane

forests, Ostrich, 80:1, 1-7. https://doi.org/10.2989/OSTRICH.2009.80.1.1.759

Onana J-M. 2011.The Vascular Plants of Cameroon. A Taxonomic Checklist with IUCN Assessments. Flore du Cameroun 39. IRAD-National Herbarium of Cameroon, Yaoundé

Onana J-M. 2017. Burseraceae. Flore du Cameroun 43. IRAD-National Herbarium of Cameroon, Yaoundé

Onana J-M, Cheek M. 2011. Red Data Book of the flowering plants of Cameroon, IUCN global assessments. Kew: Royal Botanic Gardens.

POWO. 2019. Plants of the World Online. Facilitated by the Royal Botanic Gardens, Kew. Published on the Internet; http://www.plantsoftheworldonline.org/ Retrieved 7 Nov. 2020.

Radlkofer L. 1932. Sapindaceae in Engler, A. Das Pflanzenreich IV. 165 Heft 98c. Berlin: Wilhelm Engelmann.

Sosef MSM, Wieringa JJ, Jongkind CCH, Achoundong G, Azizet Issembé Y, Bedigian D, Van Den Berg RG, Breteler FJ, Cheek M, Degreef J. 2005. Checklist of Gabonese Vascular Plants. Scripta Botanica Belgica 35. National Botanic Garden of Belgium.

Stoffelen P, Cheek M, Bridson D, Robbrecht E. 1997. A new species of Coffea (Rubiaceae) and notes on Mt Kupe (Cameroon). Kew Bulletin 52: 989-994.

https://www.jstor.org/stable/4117826

Thiers B. 2020. continuously updated. Index Herbariorum: A global directory of public herbaria and associated staff. New York Botanical Garden's Virtual Herbarium. Available at http://sweetgum.nybg.org/ih/ (accessed June 2020).

Thomas DW. 1986. Notes on Deinbollia species from Cameroon. Annals Missouri Botanic Garden 73(1): 219-221.

Thomas DW, Cheek M. 1992. Vegetation and plant species on the south side of Mount Cameroon in the proposed Etinde reserve. Report to Govt. Cameroon from ODA. Kew: Royal Botanic Gardens. 
848 Thomas DW, Harris DJ. 2000. New Sapindaceae from Cameroon and Nigeria. Kew Bulletin 849 54(4): 951-957

850

851

852

853

854 


\section{Table $\mathbf{1}$ (on next page)}

Characters separating Deinbollia onanae from $D$. grandifolia, D. maxima and D. pinnata.

Characters taken from Fouilloy \& Hallé (1973) and Keay (1958). 


\begin{tabular}{|c|c|c|c|c|}
\hline & $\begin{array}{l}\text { Deinbollia } \\
\text { grandifolia }\end{array}$ & $\begin{array}{l}\text { Deinbollia } \\
\text { maxima }\end{array}$ & $\begin{array}{l}\text { Deinbollia } \\
\text { onanae }\end{array}$ & $\begin{array}{l}\text { Deinbollia } \\
\text { pinnata }\end{array}$ \\
\hline Leaves & $\begin{array}{l}(5-) 7-10- \\
\text { jugate }\end{array}$ & 4-6-jugate & $(2-) 8-11$-jugate & $\begin{array}{l}(2-) 5-9-(-12)- \\
\text { jugate }\end{array}$ \\
\hline $\begin{array}{l}\text { Leaf rhachis adaxial } \\
\text { surface }\end{array}$ & Rounded & Rounded & $\begin{array}{l}\text { Flattened, with } \\
\text { margins angled- } \\
\text { winged, midline } \\
\text { with raised } \\
\text { ridge }\end{array}$ & $\begin{array}{l}\text { Flattened, with } \\
\text { margins angled- } \\
\text { winged, midline } \\
\text { with raised } \\
\text { ridge }\end{array}$ \\
\hline $\begin{array}{l}\text { Indumentum of } \\
\text { abaxial surface of } \\
\text { leaflet }\end{array}$ & \begin{tabular}{|l|} 
Glabrous, or \\
with a few \\
scattered \\
inconspicuous \\
hairs
\end{tabular} & $\begin{array}{l}\text { Glabrous, or } \\
\text { with a few } \\
\text { scattered } \\
\text { inconspicuous } \\
\text { hairs }\end{array}$ & $\begin{array}{l}\text { Softly hairy } \\
\text { with numerous } \\
\text { translucent, } \\
\text { patent hairs }\end{array}$ & $\begin{array}{l}\text { Glabrous, or } \\
\text { with a few } \\
\text { scattered } \\
\text { inconspicuous } \\
\text { hairs }\end{array}$ \\
\hline Leaflet width & $5-8 \mathrm{~cm}$ & $6-8(-10) \mathrm{cm}$ & $(2.1-) 2.5-4 \mathrm{~cm}$ & $\begin{array}{l}2.3-7.5(-10) \\
\mathrm{cm}\end{array}$ \\
\hline $\begin{array}{l}\mathrm{N}^{\circ} \mathrm{s} \text { pair of } \\
\text { secondary nerves } \\
\text { (distal leaflets) }\end{array}$ & $12-14(-16)$ & $8-10$ & $(12-) 17-18$ & $6-12$ \\
\hline $\begin{array}{l}\text { Fruit breadth, } \\
\text { indumentum }\end{array}$ & $\begin{array}{l}1.5 \mathrm{~cm}, \\
\text { glabresecent }\end{array}$ & $\begin{array}{l}\text { Dimensions } \\
\text { unknown, } \\
\text { glabresecent }\end{array}$ & $\begin{array}{l}1.3-1.5 \mathrm{~cm} \\
\text { tomentose }\end{array}$ & $2 \mathrm{~cm}$, glabrous \\
\hline
\end{tabular}




\section{Table 2 (on next page)}

The more significant differences between Deinbollia onanae and Deinbollia oreophila.

Data on Deinbollia oreophila from (Cheek \& Etuge, 2009) 
1 Table 2:

2 Characters separating Deinbollia onanae and Deinbollia oreophila.

3

4 Characters for Deinbollia oreophila taken from Cheek \& Etuge (2009).

\begin{tabular}{|l|l|l|}
\hline & Deinbollia oreophila & Deinbollia onanae \\
\hline Height at maturing & $0.8-3(-5) \mathrm{m}$ & $(4-) 5-10(-15) \mathrm{m}$ \\
\hline Stem indumentum & Glabrous & $\begin{array}{l}\text { Simple hairy, sparse to dense, } \\
\text { glabrescent. }\end{array}$ \\
\hline Lenticels & $\begin{array}{l}\text { Highly conspicuous, bright } \\
\text { white, contrasting with } \\
\text { epidermis }\end{array}$ & $\begin{array}{l}\text { Inconspicuous, grey-brown, } \\
\text { concolorous with epidermis }\end{array}$ \\
\hline $\begin{array}{l}\text { Length of leaves (flowering } \\
\text { stems) }\end{array}$ & $25-63 \mathrm{~cm}$ & $(14-) 60-70 \mathrm{~cm}$ \\
\hline $\begin{array}{l}\text { Number of leaflets per leaf } \\
\text { (flowering stems) }\end{array}$ & $(4-) 6-8(-10)$ & $(4-) 16-23$ \\
\hline $\begin{array}{l}\text { Width of leaflets (flowering } \\
\text { stems). }\end{array}$ & $(3-) 5.5-9(-10.2)$ cm & $(2.1-) 2.5-4$ cm \\
\hline $\begin{array}{l}N^{\circ} \text { secondary nerves each side } \\
\text { of midrib }\end{array}$ & $(7-) 9-14(-17)$ & $(15-) 17-18$ \\
\hline $\begin{array}{l}\text { Indumentum of lower surface } \\
\text { of leaf blade }\end{array}$ & Glabrous & $\begin{array}{l}\text { Inconspicuously sparsely } \\
\text { simple hairy on secondary } \\
\text { nerves and midrib }\end{array}$ \\
\hline Sepals & Orbicular, margins glabrous & Ovate, margins hairy \\
\hline Petals & $\begin{array}{l}\text { Oblong or obovate, base } \\
\text { cuneate; adaxial appendage } \\
\text { surface glabrous }\end{array}$ & $\begin{array}{l}\text { Rhombic or spatulate, basal } \\
\text { claw (stalk); adaxial appendage } \\
\text { surface hairy }\end{array}$ \\
\hline $\begin{array}{l}\text { Staminal filaments of male } \\
\text { flowers }\end{array}$ & Proximal half glabrous. & Entire length densely hairy. \\
\hline Ovary of female flowers & $\begin{array}{l}\text { 3-lobed, surface with very } \\
\text { sparse, stout hairs }\end{array}$ & $\begin{array}{l}\text { 2-lobed, densely hair with fine } \\
\text { hairs }\end{array}$ \\
\hline Altitudinal range & $(880-) 1000-2050 \mathrm{~m}$ & $(1400-) 2050-2200 \mathrm{~m}$ \\
\hline
\end{tabular}

6 


\section{Table 3 (on next page)}

The 28 montane forest trees of the Cameroon Highlands.

Data mainly from Cheek et al., (2000), updated with subsequent literature e.g. Kenfack (2011), Cheek \& Ngolan (2007), Cheek et al., (2017) and POWO (2019) 


\begin{tabular}{|c|c|c|c|c|c|}
\hline $\begin{array}{l}\text { Currently accepted } \\
\text { species name }\end{array}$ & $\begin{array}{l}\text { Former name } \\
\text { used in Cameroon } \\
\text { Highlands, if any } \\
\text { (e.g. Cheek et al., } \\
\text { 2000) }\end{array}$ & $\begin{array}{l}\text { Endemic to } \\
\text { Cameroon } \\
\text { Highlands } \\
(\mathrm{Y} / \mathrm{N})\end{array}$ & $\begin{array}{l}\text { Occurring } \\
\text { also } \\
\text { below } \\
2000 \mathrm{~m} \\
\text { alt. }(\mathrm{Y} / \mathrm{N})\end{array}$ & $\begin{array}{l}\text { Species } \\
\text { forming } \\
90 \% \text { of } \\
\text { the } \\
\text { canopy } \\
(\mathrm{Y} / \mathrm{N})\end{array}$ & $\begin{array}{l}\text { Forest } \\
\text { edge } \\
\text { species = E } \\
\text { Infrequent } \\
\text { species = } \\
\mathrm{R}\end{array}$ \\
\hline \begin{tabular}{|l|} 
Astropanax \\
abyssinica \\
(A.Rich.)Seem.
\end{tabular} & $\begin{array}{l}\text { Schefflera } \\
\text { abyssinica } \\
\text { (A.Rich.)Harms }\end{array}$ & $\mathrm{N}$ & $\mathrm{N}$ & $\mathrm{Y}$ & \\
\hline $\begin{array}{l}\text { Astropanax mannii } \\
\text { (Hook.f.)Seem. }\end{array}$ & $\begin{array}{l}\text { Schefflera mannii } \\
\text { (Hook.f.)Harms }\end{array}$ & $\mathrm{Y}$ & $\mathrm{N}$ & $\mathrm{Y}$ & \\
\hline $\begin{array}{l}\text { Prunus africana } \\
\text { (L.)Kalkman }\end{array}$ & $\begin{array}{l}\text { Pygeum } \\
\text { africanum } \\
\text { Hook.f. }\end{array}$ & $\mathrm{N}$ & $\mathrm{N}$ & $\mathrm{Y}$ & \\
\hline $\begin{array}{l}\text { Syzygium staudtii } \\
\text { (Engl.)Mildbr. }\end{array}$ & $\begin{array}{l}\text { Syzygium } \\
\text { guineense subsp. } \\
\text { bamendae } \\
\text { F.White }\end{array}$ & $\mathrm{N}$ & $\mathrm{N}$ & $\mathrm{Y}$ & \\
\hline $\begin{array}{l}\text { Myrsine } \\
\text { melanophloeos } \\
\text { (L.)Sweet }\end{array}$ & $\begin{array}{l}\text { Rapanea } \\
\text { melanophloeos } \\
\text { (L.)Mez }\end{array}$ & $\mathrm{N}$ & $\mathrm{N}$ & $\mathrm{Y}$ & \\
\hline $\begin{array}{l}\text { Oldeania alpina } \\
\text { (K.Schum.)Stapleton }\end{array}$ & $\begin{array}{l}\text { Arundinaria } \\
\text { alpina K.Schum. }\end{array}$ & $\mathrm{N}$ & $\mathrm{N}$ & $\mathrm{Y}$ & \\
\hline $\begin{array}{l}\text { Carapa oreophila } \\
\text { Kenfack }\end{array}$ & $\begin{array}{l}\text { Carapa } \\
\text { grandiflora } \\
\text { Sprague }\end{array}$ & $\mathrm{Y}$ & $\mathrm{N}$ & $\mathrm{Y}$ & \\
\hline $\begin{array}{l}\text { Bersama abyssinica } \\
\text { Fresen. }\end{array}$ & & $\mathrm{N}$ & $\mathrm{N}$ & $\mathrm{Y}$ & \\
\hline Ixora foliosa Hiern & & $\mathrm{Y}$ & $\mathrm{N}$ & $\mathrm{Y}$ & \\
\hline $\begin{array}{l}\text { Clausena anisata } \\
\text { (Willd.)Benth, }\end{array}$ & & $\mathrm{N}$ & $\mathrm{Y}$ & $\mathrm{Y}$ & \\
\hline $\begin{array}{l}\text { Nuxia congesta } \\
\text { Fresen. }\end{array}$ & & $\mathrm{N}$ & $\mathrm{N}$ & $\mathrm{N}$ & $\mathrm{E}$ \\
\hline $\begin{array}{l}\text { Lasiosiphon glaucus } \\
\text { Fresen. }\end{array}$ & $\begin{array}{l}\text { Gnidia glauca } \\
\text { (Fresen.) Gilg }\end{array}$ & $\mathrm{N}$ & $\mathrm{N}$ & $\mathrm{N}$ & $\mathrm{E}$ \\
\hline $\begin{array}{l}\text { Hypericum revolutum } \\
\text { Vahl subsp. } \\
\text { revolutum }\end{array}$ & & $\mathrm{N}$ & $\mathrm{N}$ & $\mathrm{N}$ & $E$ \\
\hline $\begin{array}{l}\text { Maesa lanceolata } \\
\text { G.Don }\end{array}$ & & $\mathrm{N}$ & $\mathrm{N}$ & $\mathrm{N}$ & $\mathrm{E}$ \\
\hline $\begin{array}{l}\text { Alsophila dregei } \\
\text { (Kunze)R.M.Tryon }\end{array}$ & $\begin{array}{l}\text { Cyathea dregei } \\
\text { Kunze }\end{array}$ & $\mathrm{N}$ & $\mathrm{N}$ & $\mathrm{N}$ & $\mathrm{E}$ \\
\hline $\begin{array}{l}\text { Podocarpus latifolius } \\
\text { (Thunb.)Mirb. }\end{array}$ & & $\mathrm{N}$ & $\mathrm{Y}$ & $\mathrm{N}$ & $\mathrm{R}$ \\
\hline Croton & & $\mathrm{N}$ & $\mathrm{Y}$ & $\mathrm{N}$ & $\mathrm{R}$ \\
\hline
\end{tabular}




\begin{tabular}{|c|c|c|c|c|c|}
\hline macrostachyus Delile & & & & & \\
\hline $\begin{array}{l}\text { Albizia gummifera } \\
\text { (J.F.Gmel)C.A.Smith }\end{array}$ & & $\mathrm{N}$ & $\mathrm{Y}$ & $\mathrm{N}$ & $\mathrm{R}$ \\
\hline $\begin{array}{l}\text { Cassipourea } \\
\text { malosana } \\
\text { (Baker)Alston }\end{array}$ & & $\mathrm{N}$ & $\mathrm{N}$ & $\mathrm{N}$ & $\mathrm{R}$ \\
\hline $\begin{array}{l}\text { Brucea } \\
\text { antidysenterica } \\
\text { J.F.Mill. }\end{array}$ & & $\mathrm{N}$ & $\mathrm{N}$ & $\mathrm{N}$ & $\mathrm{R}$ \\
\hline Ilex mitis (L.)Radlk. & & $\mathrm{N}$ & $\mathrm{N}$ & $\mathrm{N}$ & $\mathrm{R}$ \\
\hline $\begin{array}{l}\text { Neoboutonia mannii } \\
\text { Benth. \& Hook.f. }\end{array}$ & $\begin{array}{l}\text { Neoboutonia } \\
\text { glabrescens } \text { Prain }\end{array}$ & $\mathrm{N}$ & $\mathrm{Y}$ & $\mathrm{N}$ & $\mathrm{R}$ \\
\hline $\begin{array}{l}\text { Olea capensis subsp. } \\
\text { macrocarpa } \\
\text { (C.H.Wright)I.Verd. }\end{array}$ & Olea capensis & $\mathrm{N}$ & $\mathrm{N}$ & $\mathrm{N}$ & $\mathrm{R}$ \\
\hline $\begin{array}{l}\text { Eugenia gilgii Engl. } \\
\text { \& Brehmer }\end{array}$ & & $\mathrm{Y}$ & $\mathrm{N}$ & $\mathrm{N}$ & $\mathrm{R}$ \\
\hline $\begin{array}{l}\text { Agarista salicifolia } \\
\text { (Lam.)G.Don }\end{array}$ & $\begin{array}{l}\text { Agauria } \\
\text { salicifolia } \\
\text { (Lam.)Oliv. }\end{array}$ & $\mathrm{N}$ & $\mathrm{N}$ & $\mathrm{N}$ & $\mathrm{R}$ \\
\hline $\begin{array}{l}\text { Dovyalis } \\
\text { cameroonensis Cheek } \\
\text { \& Ngolan }\end{array}$ & Dovyalis sp.nov. & $\mathrm{Y}$ & $\mathrm{N}$ & $\mathrm{N}$ & $\mathrm{R}$ \\
\hline $\begin{array}{l}\text { Ternstroemia } \\
\text { cameroonensis Cheek }\end{array}$ & $\begin{array}{l}\text { Ternstroemia } \\
\text { polypetala Melch. }\end{array}$ & $\mathrm{Y}$ & $\mathrm{Y}$ & $\mathrm{N}$ & $\mathrm{R}$ \\
\hline $\begin{array}{l}\text { Deinbollia onanae } \\
\text { Cheek }\end{array}$ & Deinbollia sp. 2 & $\mathrm{Y}$ & $\mathrm{Y}$ & $\mathrm{N}$ & $\mathrm{R}$ \\
\hline
\end{tabular}




\section{Figure 1}

Deinbollia onanae.

(A) habit, flowering branch; (B) detail from a large leaf showing apex and distal leaves (adaxial surfaces) and second leaf from the base (abaxial surface); (C) male flower lateral view; (D) male flower, petals and sepals removed to show the extra staminal disc and androecium; (E) base of $D$ (male flower) showing the vestigial gynoecium and disc cut to show notches holding filament bases; (F) petal, adaxial surface, male flower; (G) female flower, lateral view; (H) female flower (with 3 sepals, 2 petals and anterior stamens removed) to show gynoecium and disc; (I) stamen from female flower; (J) petal, adaxial surface, of female flower with stamen. A, C-J from de Wilde et al. 4553 (K); B from Cheek 13436 (K). Drawn by Andrew Brown. 


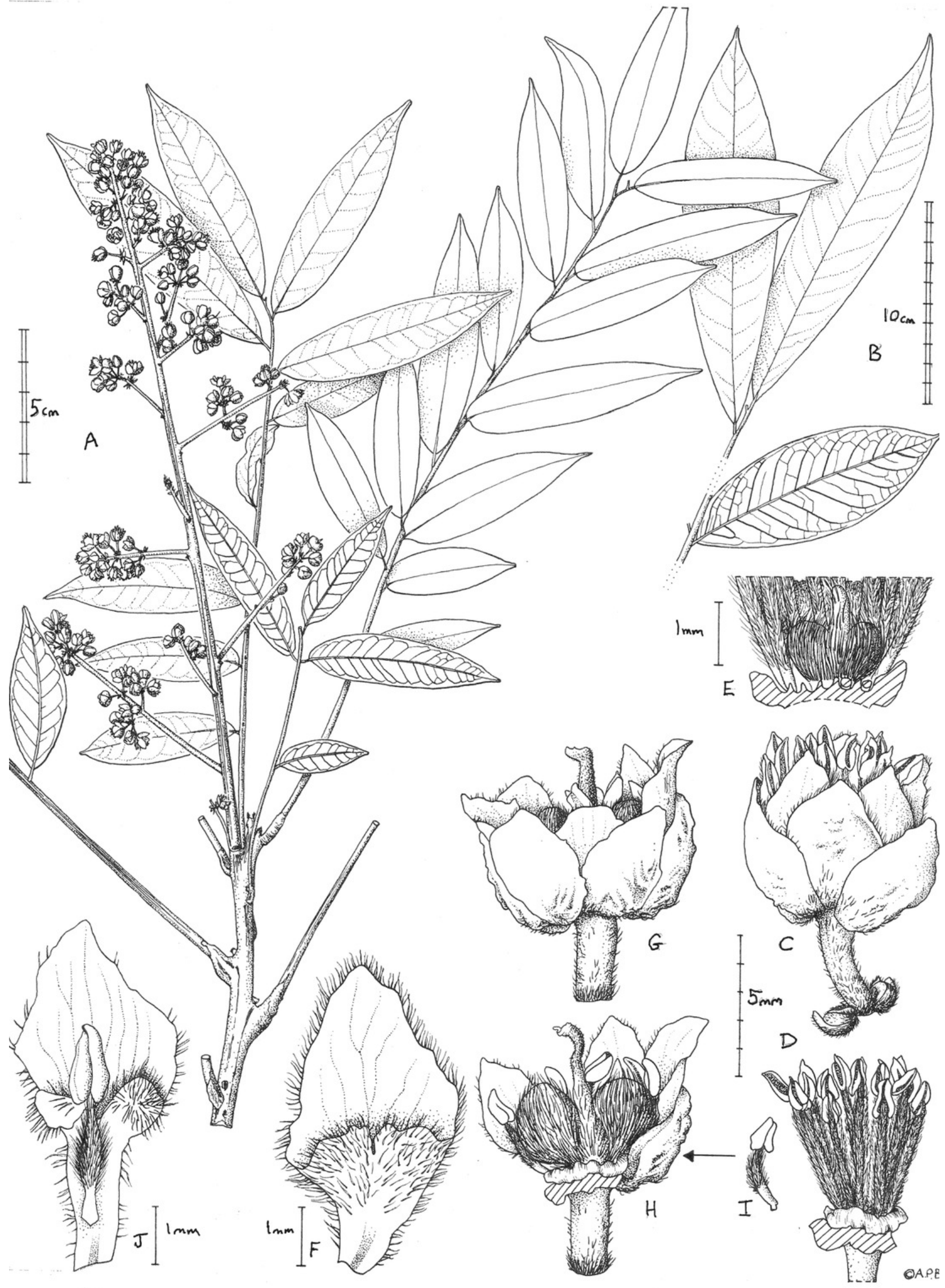


Figure 2

Deinbollia onanae.

Photo of the holotype: Etuge 3600 (holotypus K000593309). Photo by Xander van der Burgt.

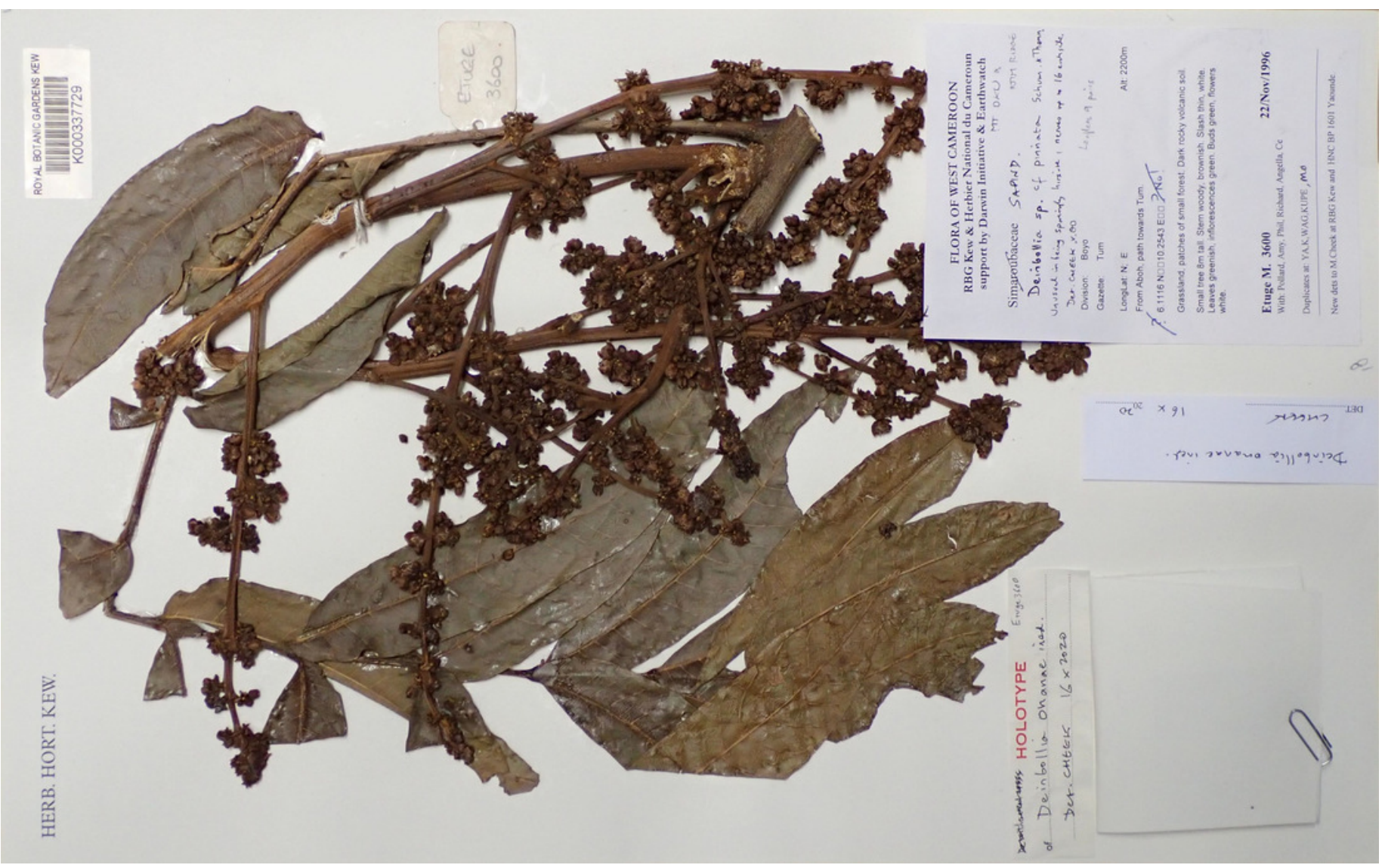


Figure 3

Deinbollia onanae. Global distribution map. By Xander van der Burgt.

By Xander van der Burgt.

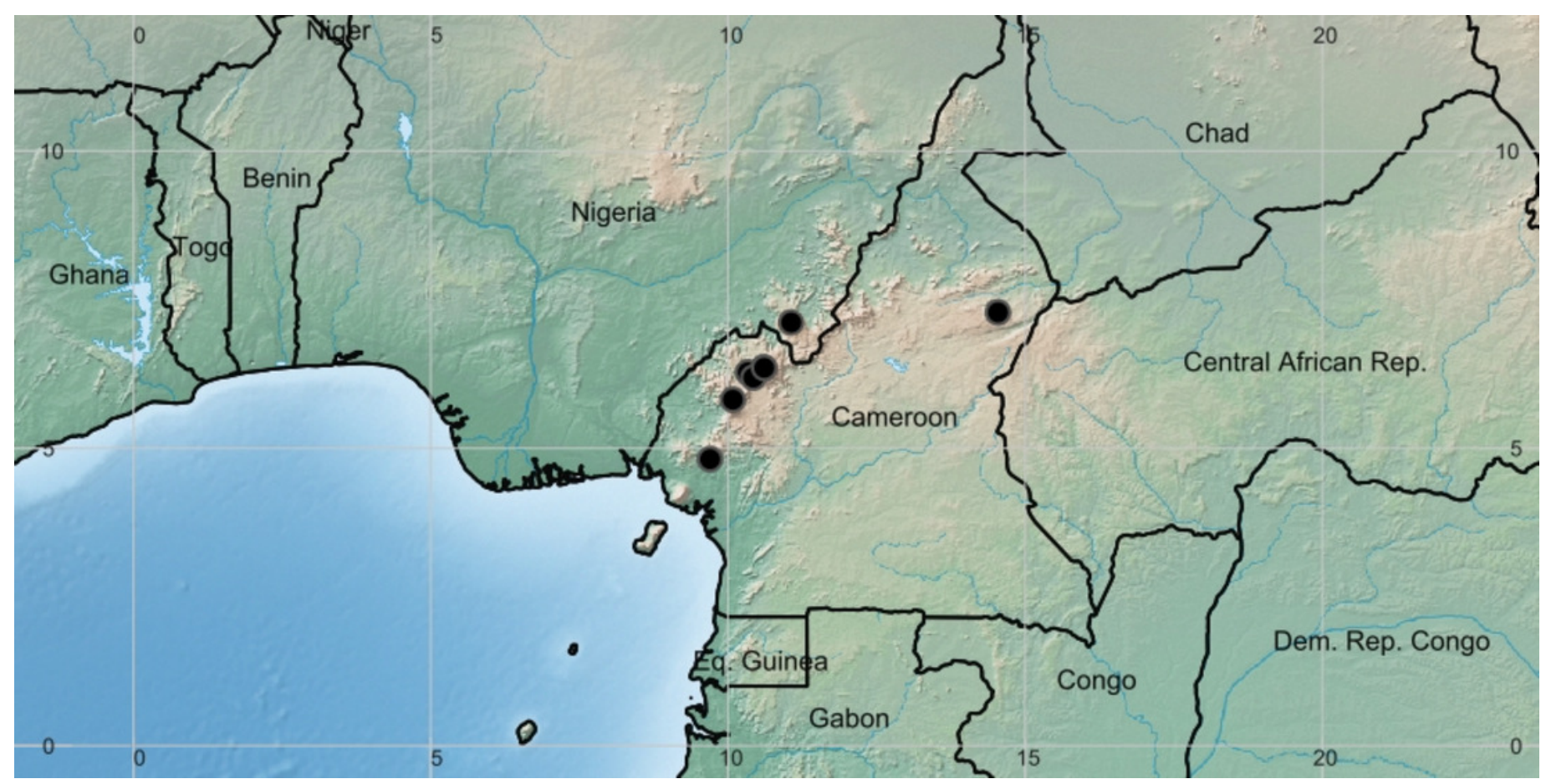


Figure 4

Figure 4: Deinbollia onanae.

Habit of tree in flower at Ngel Nyaki, Nigeria. Photo by Max Walters. Source: Nickrent $D L$,

Costea M, Barcelona JF et al. (2006 onwards)

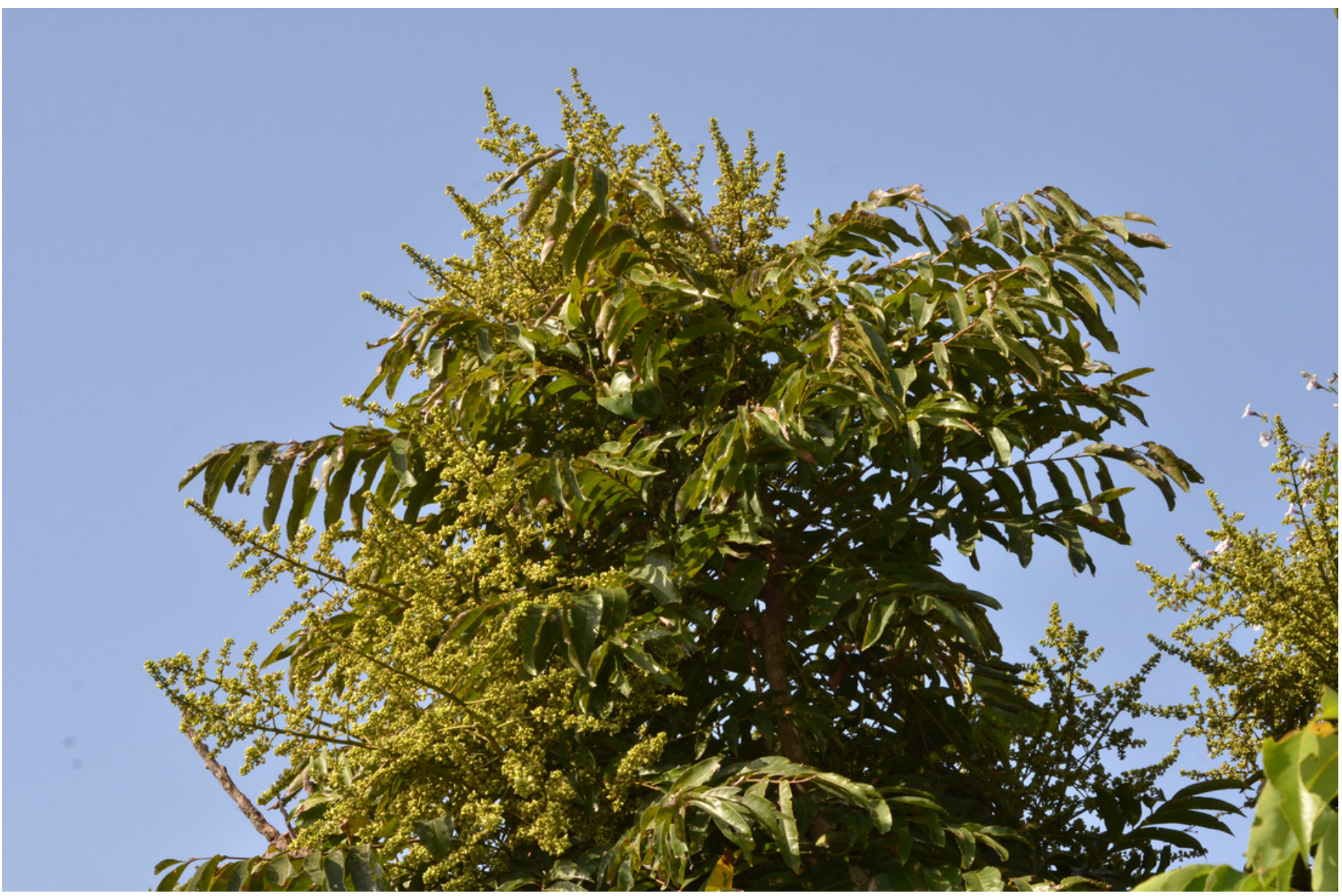

